\title{
EVALUATION OF ANTIRADICAL SCAVENGER ACTIVITY OF EXTRACT AND COMPOUNDS FROM ETLINGERA CALOPHRYS STEMS
}

\author{
SAHIDIN I ${ }^{1 *}$, WAHYUNI ${ }^{1}$, MUH. HAJRUL MALAKA ${ }^{1}$, JABBAR A ${ }^{1}$, IMRAN ${ }^{2}$, MARIANTI A MANGGAU ${ }^{3}$ \\ ${ }^{1}$ Department of Pharmacy, Faculty of Pharmacy, Universitas Halu Oleo, Kendari 93232, Indonesia. ${ }^{2}$ Department of Chemistry, Faculty of \\ Mathematics and Natural Sciences, Universitas Halu Oleo, Kendari 93232, Indonesia. ${ }^{3}$ Department of Pharmacy, Faculty of Pharmacy, \\ Universitas Hasanuddin, Makassar 90245, Indonesia. Email: sahidin02@yahoo.com
}

Received: 13 September 2017, Revised and Accepted: 14 November 2017

ABSTRACT

Objective: This study was aimed to isolate and identify the chemical compounds from the methanol extract of the stems of Etlingera calophrys as well as to evaluate their potential as free radical scavengers.

Methods: The isolated compounds were obtained using vacuum liquid chromatography (VLC) and radial chromatography techniques. The structures of these compounds were determined on the basis of their measured spectroscopic evidence (infrared, one dimentional (1D), and 2D nuclear magnetic resonance) and by comparison with literature data. The free radical scavenging activity of the methanol extract of the stems and the isolated compounds were measured using qualitative and quantitative 2,2-diphenyl-1-picrylhydrazyl (DPPH) assays.

Results: Yakuchinone A (1), p-hydroxybenzoic acid (2), and stigmasterol (3) were successfully isolated and identified from the stems of E. calophyrs. The methanol extract and compounds $1-3$ showed free radical scavenging activity with half maximal inhibitory concentration (IC ${ }_{50}$ ) values of 38.36 , $39.07,46.60$, and $153.4 \mu \mathrm{g} / \mathrm{mL}$, respectively, as compared to ascorbic acid with an $\mathrm{IC}_{50}$ value of $10.53 \mu \mathrm{g} / \mathrm{mL}$.

Conclusions: Yakuchinone A (1) and p-hydroxybenzoic acid (2) are first reported from the genus Etlingera. The presence of these compounds may contribute to the free radical scavenging activity of the methanol extract of the stems of E. calophrys. This finding suggested that E. calophrys may serve as a source of natural antioxidant compounds and could be used in the development of antioxidant herbal preparation.

Keywords: Etlingera calophrys, Zingiberaceae, Stem extract, Compounds, 2,2-diphenyl-1-picrylhydrazyl.

(C) 2018 The Authors. Published by Innovare Academic Sciences Pvt Ltd. This is an open access article under the CC BY license (http://creativecommons. org/licenses/by/4. 0/) DOI: http://dx.doi.org/10.22159/ajpcr.2018.v11i2.22535

\section{INTRODUCTION}

As part of continuing study on traditional medicinal plants, we investigated the chemistry and pharmacological aspects of Etlingera species. Our previous study included plants species from Dipterocarpaceae [1-4], Jatropha [5-7], Annonaceae [8], Pongamia [9], Imperata [10], Polygonum [11,12], and Dillenia [13].

Zingiberaceae is one of the common plants in Indonesia used as traditional medicines [14]. The genus Etlingera belongs to the Zingiberaceae family and contains approximately 150-200 species of worldwide distribution. Of these, as many as 54 species of this genus have been recorded in Indonesia, including 48 species from Sulawesi, and 6 species from Java [15]. Species of this genus have been used in medicinal folklore to treat various ailments, and the presence of the volatile and non-volatile entities in these species has gained research interests among scientists.

Previous studies revealed the presence of phenylpropanoids, flavonoids, and phytosterols in the species of Etlingera. The leaves of Etlingera elatior produced quinic acid-containing cinnamic acid derivatives, including 3-O-caffeoylquinic acid, 5-O-caffeoylquinic acid (chlorogenic acid), and 5-O-caffeoylquinic acid methyl ester [16]. In addition, its leaves also contained kaempferol-3glucuronide, quercetin-3-glucuronide, quercetin-3-glucoside, and quercetin-3-rhamnoside [17]. Moreover, leaves and rhizomes of Etlingera brevilabrum and Etlingera sphaerochepala var. grandiflora produced $\beta$-sitosterol and stigmasterol $[18,19]$. The latter species also yielded a simple phenolic paeonol [19].
Different parts of Etlingera species also have proven to have promising biological activities. Leaves and stems of E. brevilabrum exhibited anticholesterol activity [18], while the leaves and rhizomes of E. elatior performed antioxidant, antibacterial, and tyrosinase inhibitory activity $[17,20-25]$. Antibacterial and antioxidant activities also exhibited by the leaves extract of E. fulgens [20]. Other studies revealed the potency of $E$. littoralis rhizomes and E. maingayi leaves as antibacterial agents [26]. Moreover, essential oil of Etlingera fenzlii (Kurz) K. Schaum was safe for repellent source [27].

Species Etlingera calophrys (K. Schum) A. D. Poulsen is an endemic plant species from Sulawesi Tenggara [15]. To our knowledge, the chemistry and pharmacology aspects of this plant have not been investigated thus far, requiring more research. Hence, the present work will facilitate and report the isolation and identification of chemical compounds from the methanol extract of E. calophrys stems, as well as their antioxidant activity based on the capacity to scavenge 2,2-diphenyl-1-picrylhydrazyl (DPPH) free radicals.

\section{MATERIALS AND METHODS}

\section{General procedures}

Instruments were used Cary Varian 100 Conc. UV spectrophotometer, PerkinElmer Spectrum One fourier transform-IR spectrophotometer, and JEOL ECP 500 nuclear magnetic resonance (NMR) spectrometer (500 MHz for ${ }^{1} \mathrm{H}$ and $125 \mathrm{MHz}$ for ${ }^{13} \mathrm{C}$ ). Chromatography techniques were performed using Kieselgel $60 \mathrm{~F}_{254} 0,25 \mathrm{~mm}$, silica gel $60 \mathrm{GF}_{254}$, and silica 60 g (Merck, Darmstadt, Germany). Thin-layer chromatography (TLC) plates were derivatized using a cerium sulfate reagent (Merck, 
Darmstadt, Germany). DPPH was purchased from Merck (Darmstadt, Germany).

\section{Sample}

Stems of E. calophrys were collected from the Wolasi Forest, South Konawe, Sulawesi Tenggara, in April 2016. The plant specimen was identified and stored in the Herbarium Bogoriense, Indonesia.

\section{Extraction and isolation}

The dried powdered stems of E. calophrys (3kg, 230-270 mesh) were macerated with methanol $(\mathrm{MeOH}, 3 \times 7.5 \mathrm{~L}, 24$ h each time) at room temperature and yielded a dried methanol extract as a dark green gum $(150 \mathrm{~g})$. This extract was further fractionated using a silica gel vacuum liquid chromatography (VLC) $(10 \times 5 \mathrm{~cm}, 150 \mathrm{~g})$, eluted with $n$-hexaneethyl acetate (from 8:2 to 0:10) followed by pure $\mathrm{MeOH}$, and gave 5 main fractions (F1-F5) with weight of 1.1, 5.0, 10.3, 10.2, and $58.4 \mathrm{~g}$, respectively. Main fraction F2 was re-fractionated using a silica gel VLC $(5 \times 5 \mathrm{~cm}, 50 \mathrm{~g})$ and gradient eluted with $n$-hexane-ethylacetate (from 7:3 to $0: 10$ ) and $\mathrm{MeOH}$ as mobile phases, to yield subfractions F21 (0.2 g), F22 (1.0 g), F23 (0.8 g), and F24 (1.2 g). Subfraction F23 was chromatographed using a silica gel radial chromatography (RC) with chloroform-MeOH (95:5) and pure $\mathrm{MeOH}$ as mobile phases, to produce pure compound $1(0.2 \mathrm{~g})$. Furthermore, the main fraction F3 was subjected to a silica gel VLC $(10 \times 5 \mathrm{~cm}, 150 \mathrm{~g})$, separated gradient with $n$-hexane-ethyl acetate (from 6:4 to 0.10 ) followed by pure $\mathrm{MeOH}$, and afforded subfractions F31 (0.3 g), F32 (1.2 g), F33 (1.8 g), F34 (1.2 g), and F35 (3.4 g). Subfraction F33 was further purified using silica gel RC with elution of $n$-hexane-ethyl acetate (85:15) followed by pure $\mathrm{MeOH}$, to give pure compound 2 (0.1 g). Subfraction F34 was also purified using silica gel RC, separated using a mixture of $n$-hexane-ethyl acetate (75:25) and $\mathrm{MeOH}$, and yielded pure compound $\mathbf{3}(0.05 \mathrm{~g})$.

\section{Radical scavenger activity}

The antioxidant activity of methanol extract and isolated compounds from E. calophrys was evaluated using qualitative and quantitative DPPH methods [28,29] with slight modifications. For qualitative analysis, sample was applied on a TLC plate within the concentration range of $0.1-100 \mu \mathrm{g}$, developed using a suitable mobile phase and dried at room temperature. The dried plate was then sprayed with DPPH solution $(0.2 \%$ in $\mathrm{MeOH})$ and incubated for 30 min in the dark at room temperature. The observation of active samples was made based on the intensity of yellow spots against the purple background on the plate. Furthermore, for quantitative analysis, triplicate $1 \mathrm{~mL}$ aliquots of samples were mixed with $1 \mathrm{~mL}$ of DPPH solution $(500 \mu \mathrm{M} ; 0.2 \mathrm{mg} / \mathrm{m})$ and incubated for $30 \mathrm{~min}$ in the dark at room temperature. The absorption was measured spectrophotometrically at $517 \mathrm{~nm}$ against methanol as a blank. The amount of sample at which the absorbance at $517 \mathrm{~nm}$ decreased a half from the initial value was determined as the half maximal inhibitory concentration $\left(\mathrm{IC}_{50}\right.$ ) value, expressed in $\mu \mathrm{g} / \mathrm{mL}$. Ascorbic acid was used as positive control.

\section{RESULTS}

Physicochemical property and spectroscopic data of the isolated compounds from E. calophrys

Three chemical compounds (1-3) were successfully isolated and identified from the methanol extract of E. calophrys stems. Structures of these compounds were determined based on their physicochemical property and spectroscopic spectra of IR and NMR. These values were also compared with those reported in the previous studies.

Yakuchinone A (1); yellow oil; ${ }^{1} \mathrm{HNMR}\left(500 \mathrm{MHz}, \mathrm{CDCl}_{3}\right) \delta_{\mathrm{H}}(\mathrm{ppm})$ : 7.28 (m, 2H, H-2"/H-6"), 7.18 (m, 3H, H-3"/H-4"/H-5"), 6.84 (m, 3H, H-5'), 6.67 (dd, J = 4.06 Hz, 2H, H-2'/H-6'), 5.62 (s, 1H, OH), 3.84 (s, 3H, $\left.\mathrm{OCH}_{3}\right), 2.83(\mathrm{t}, J=7.45 \mathrm{~Hz}, 2 \mathrm{H}, \mathrm{H}-1), 2.69(\mathrm{t}, J=7.45 \mathrm{~Hz}, 2 \mathrm{H}, \mathrm{H}-2), 2.61(\mathrm{t}$, $J=7.1 \mathrm{~Hz}, 2 \mathrm{H}, \mathrm{H}-7), 2.41(\mathrm{t}, J=6.83 \mathrm{~Hz}, 2 \mathrm{H}, \mathrm{H}-4), 1.61(\mathrm{t}, J=3.58 \mathrm{~Hz}, 4 \mathrm{H}$, $\mathrm{H}-5 / \mathrm{H}-6) ;{ }^{13} \mathrm{CNMR}\left(125 \mathrm{MHz}, \mathrm{CDCl}_{3}\right) \delta_{\mathrm{c}}(\mathrm{ppm}): 210.5$ (C-3), 146.5 (C-3'), 144.0 (C-4'), 142.3 (C-1"), 133.8 (C-1'), 128.5 (C-3"/C-5"), 125.9 (C-4"), 128.4 (C-2"/C-6"), 120.9 (C-6'), 114.5 (C-5'), 111.2 (C-2'), $55.9\left(\mathrm{OCH}_{3}\right)$,
44.7 (C-2), 43.0 (C-4), 35.8 (C-7), 31.1 (C-6), 29.6 (C-1), 23.5 (C-5). NMR spectral data were identical to those given in Chacha et al. [28].

p-Hydroxybenzoic acid (2); white amorphous powder, ${ }^{1} \mathrm{HNMR}(500 \mathrm{MHz}$, $\left.\mathrm{CDCl}_{3}\right) \delta_{\mathrm{H}}(\mathrm{ppm}): 7.91(\mathrm{~d}, J=8.4 \mathrm{~Hz}, 2 \mathrm{H}, \mathrm{H}-2 / \mathrm{H}-6), 6.91(\mathrm{~d}, J=8.4 \mathrm{~Hz}, 2 \mathrm{H}$, $\mathrm{H}-3 / \mathrm{H}-5) ;{ }^{13} \mathrm{CNMR}\left(125 \mathrm{MHz}, \mathrm{CDCl}_{3}\right.$ ) $\delta_{\mathrm{C}}$ (ppm): 167.6 (C-7), 162.7 (C-4), 132.6 (C-2/C-6), 122.6 (C-1), 115.9 (C-3/C-6). NMR spectral data were identical to those given in Fidrianni et al. [29].

Stigmasterol (3); white needle crystal; mp: $169-171 ;{ }^{1} \mathrm{HNMR}(500 \mathrm{MHz}$, $\left.\mathrm{CDCl}_{3}\right) \delta_{\mathrm{H}}(\mathrm{ppm}): 5.35$ (br d, $\left.1 \mathrm{H}, \mathrm{H}-6\right), 5.15$ (dd, $\left.J=15 \mathrm{~Hz}, \mathrm{H}-22\right), 5.02$ (dd, $J=15 \mathrm{~Hz}, 1 \mathrm{H}, \mathrm{H}-23), 3.35$ (m, 1H, H-3), 2.27 (m, 1H, H-4a), 2.22 (m, 1H, H-4b), 2.02 (m, 1H, H-12), 1.97 (m, 1H, H-20), 1.95 (m, 1H, H-2a), 1.93 (m, 2H, H-7, 1.85 (m, 1H, H-2b), $1.82(\mathrm{~m}, 1 \mathrm{H}, \mathrm{H}-1 \mathrm{a}), 1.66$ (m, 1H, $\mathrm{H}-25), 1.54$ (m, 2H, H-15), 1.49 (m, 1H, H-8), 1.47 (m, 2H, H-11), 1.44 (m, 2H, H-28), 1.27 (m, 1H, H-16), 1.15 (m, 1H, H-1b), 1.08 (m, 1H, $\mathrm{H}-17$ ), 1.00 (br s, 3H, H-21), 1.00 (br s, 3H, H-19), 1.00 (br s, 1H, H-26a), 0.97 (m, 1H, H-14), 0.91 (m, 1H, H-24), 0.91 (br d, 1H, H-9), 0.91 (br d, 1H, H-27a), 0.84 (br d, 1H, H-29a), 0.84 (br d, 1H, H-18a), 0.81 (br d, 2H, H-26b), 0.81 (br d, 1H, H-27b), 0.79 (br d, 1H, H-29b), 0.79 (br d, 1H, H-18b), 0.69 (br s, 1H, H-27c), 0.67 (br s, 1H, H-29c), 0.67 (br s, $1 \mathrm{H}, \mathrm{H}-18 \mathrm{c}$ ); ${ }^{13} \mathrm{CNMR}\left(125 \mathrm{MHz}, \mathrm{CDCl}_{3}\right.$ ) $\delta_{\mathrm{c}}$ (ppm): 141.9 (C-5), 138.5 (C22), 129.4 (C-23), 121.9 (C-6), 71.9 (C-3), 56.9 (C-14), 56.2 (C-17), 51.4 (C-24), 50.3 (C-9), 42.5 (C-4/C-13), 40.7 (C-20), 39.9 (C-12), 37.4 (C-1), 36.7 (C-10), 32.1 (C-7/C-8), 31.8 (C-2), 31.1 (C-25), 28.4 (C-16), 26.3 (C-28), 24.4 (C-15), 21.3 (C-19/C-21), 21.2 (C-11), 19.2 (C-26), 19.0 (C27), 12.2 (C-29), 12.0 (C-18). NMR spectral data were identical to those given in Yahya et al. [19].

\section{Free radical scavenging activity}

Table 1 summarizes the DPPH free radical scavenging activity of methanol extract and isolated compounds from E. calophyrs stems. The lowest $\mathrm{IC}_{50}$ was achieved by the methanol extract followed by yakuchinone A (1), p-hydroxybenzoic acid (2), and stigmasterol (3).

\section{DISCUSSION}

Purification of the methanol extract of E. calophrys stems using silica gel chromatography techniques resulted in the isolation of yakuchinone A (1), p-hydroxybenzoic acid (2), and stigmasterol (3). To our knowledge, the presence of the three compounds in E. calophrys was reported for the first time in the present work. Compound 1, classified as a diarylheptanoid was first reported from the fruits of Alpinia oxyphylla (Zingiberaceae) [30]. The presence of this compound in E. calophrys is considered unique since its occurrence in other investigated Etlingera species has not been recorded. Meanwhile, compound 2 is one of the common phenolic acids that can be found in most plant species. This compound is present in lignins structures that are components of plant cell walls [31]. Similarly, compound 3 is a common steroid found in plants and has been reported from E. brevilabrum leaves and rhizomes [18] and E. sphaerochepala var. Glandiflora rhizomes [19]. Structures of these compounds are displayed in Fig. 1.

Methanol extract of E. calophrys stems exhibited significant free radical scavenging activity as compared to ascorbic acid as positive control. Compounds 1-3 isolated from this extract also performed scavenging activity toward DPPH radicals. However, their activities

Table 1: $\mathrm{IC}_{50}$ values of methanol extract and compounds 1-3 toward DPPH radical

\begin{tabular}{ll}
\hline Sample & IC $_{\mathbf{5 0}}(\mu \mathrm{g} / \mathbf{m L})$ \\
\hline Methanol extract & 38.36 \\
Yakuchinone A (1) & 39.07 \\
$p$-Hydroxyl benzoic acid (2) & 46.60 \\
Stigmasterol (3) & 153.4 \\
Ascorbic acid (positive control) & 10.53 \\
\hline
\end{tabular}

$\mathrm{IC}_{50}$ : Half maximal inhibitory concentration,

DPPH: 2,2-diphenyl-1-picrylhydrazyl 


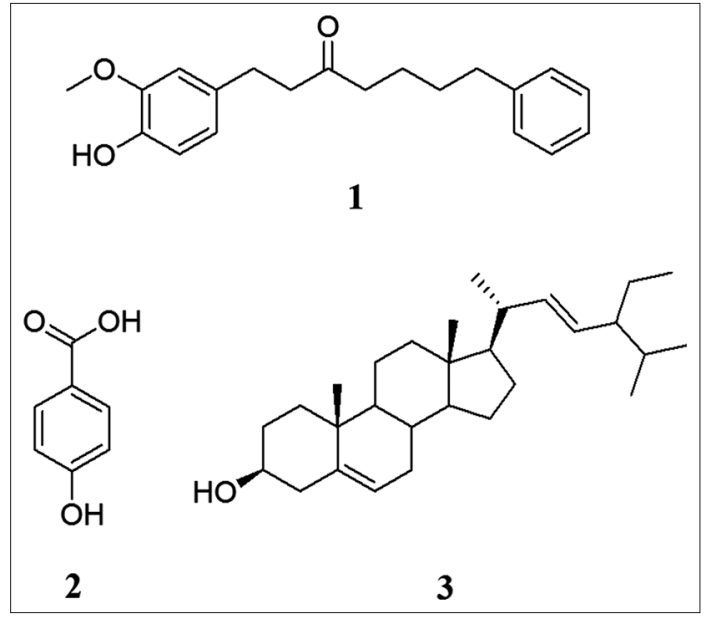

Fig. 1: Structures of compounds 1-3

were considered lower than the methanol extract, indicating by high $\mathrm{IC}_{50}$ values (Table 1). This also indicated that there may be other entities in the methanol extract that synergistically enhanced the scavenging activity. Nevertheless, yakuchinone A (1) showed potent scavenging activity among the isolated compounds, in agreement with the previous study [32]. Hence, this compound could be developed as natural antioxidant agent. Structurally, compound 1 possessed two aromatic units that may play important role to scavenge DPPH radicals by producing DPPH-H as by-product [33]. Meanwhile, compound 2 has one aromatic unit in which its scavenging activity was lower than compound 1 . In contrast, compound 3 showed very weak free radical scavenging activity, in agreement with our previous study [11]. The presence of this compound in the methanol extract of E. calophrys stems may contribute antagonistically in reducing the scavenging activity.

\section{CONCLUSION}

Three secondary metabolites were isolated from the methanol extract of $E$. calophrys stems, including yakuchinone A, $p$-hydroxybenzoic acid, and stigmasterol. Of these, yakuchinone $\mathrm{A}$ and $p$-hydroxybenzoic acid are first isolated from the genus Etlingera. On biological activities, potency of the crude methanol extracts as an antiradical agent was supported by the activity of isolated compounds. The methanol extract and isolated compounds from this plant, in particular, yakuchinone A and $p$-hydroxybenzoic acid could be used in the development of natural antioxidant agents.

\section{ACKNOWLEDGMENTS}

We would like to thank to The Ministry of Research, Technology and Higher Education of The Republic of Indonesia for the Research grant "Hibah Kompetensi 2017".

\section{AUTHORS CONTRIBUTION}

Sahidin I: Isolation and structure determination of all compounds; Manuscript writing, Wahyuni: Radical scavenger evaluation, Muh. Hajrul Malaka: Sample collection; Structure determination, Jabbar A: Radical scavenger evaluation; Sample collection, Imran: Sample determination; Isolation of compounds, Marianti A. Manggau: Manuscript writing; Radical scavenger evaluation.

\section{CONFLICT OF INTEREST}

I certify that I have participated sufficiently in the conception and design of this work entitled "EVALUATION OF ANTIRADICAL SCAVENGER ACTIVITY OF EXTRACT AND COMPOUNDS FROM ETLINGERA CALOPHRYS STEMS " and the analysis of the data, as well as writing of this manuscript, to take public responsibility for it. I believe the manuscript represents valid work. I have reviewed the final version of manuscript and approve it for publication. The manuscript is not published elsewhere, in any language, and is not under simultaneous consideration by any other journal. All Authors agree that the contents of the manuscript are confidential and will not be copyrighted, submitted, or published elsewhere (including the Internet), in any language, while acceptance by the Journal is under consideration. Furthermore I attest that I shall produce the data upon which the manuscript is based for examination by the editors or their assignees, if requested.

\section{REFERENCES}

1. Sahidin, Hakim EH, Juliawaty LD, Syah YM, bin Din L, Ghisalberti EL, et al. Cytotoxic properties of oligostilbenoids from the tree barks of Hopea dryobalanoides. Z Naturforsch C 2005;60:723-7.

2. Juliawaty LD, Sahidin, Hakim EH, Achmad SA, Syah YM, Latip J, et al. A 2-arylbenzofuran derivative from Hopea mengarawan. Nat Prod Commun 2009;4:947-50.

3. Muhammad N, Din LB, Sahidin I, Hashim SF, Ibrahim N, Zakaria Z, et al. Acuminatol and other antioxidative resveratrol oligomers from the stem bark of Shorea acuminata. Molecules 2012;17:9043-55.

4. Sahidin I, Wahyuni W, Malaka MH, Imran I. Antibacterial and cytotoxic potencies of stilbene oligomers from stem barks of Baoti (Dryobalanops lanceolata) growing in Kendari-Indonesia. Asian J Pharm Clin Res 2017;10:139-43.

5. Sahidin I, Ardiansyah S, Taher M, Manggau MA. Terpenoids from the stem bark of Jatropha plants and their biological activities. Makara Sains 2011;15:106-10.

6. Sahidin I, Yamin N, Ginting S, Manggau MA, Lukman L. Cytotoxic potency of diterpenes from Jatropha plants. Int J Pharm Pharm Sci 2013;5:3-6.

7. Sabandar CW, Ahmat N, Jaafar FM, Sahidin I. Medicinal property, phytochemistry and pharmacology of several Jatropha species (Euphorbiaceae): A review. Phytochemistry 2013;85:7-29.

8. Rosandy AR, Din LB, Yaacob WA, Yusoff NI, Sahidin I, Latip J, et al. Isolation and characterization of compounds from the stem bark of Uvaria rufa (Annonaceae). Malays J Anal Sci 2013;17:50-8.

9. Al Muqarrabun LM, Ahmat N, Ruzaina SA, Ismail NH, Sahidin I. Medicinal uses, phytochemistry and pharmacology of Pongamia pinnata (L.) Pierre: A review. J Ethnopharmacol 2013;150:395-420.

10. Ruslin M, Asmawi MZ, Rianse U, Sahidin I, Dhianawaty D, Soemardji AA, et al. Anti-hypertensive activity of alang-alang (Imperata cylindrica L.) Beauv. Root methanolic extract on male Wistar rat. Int J Res Pharm Sci 2013;4:537-42.

11. Sahidin I, Nohong N, Sani A, Manggau MA, Sukohar A, Widodo H, et al. Radical scavenging activity of triterpene steroids from stem of Polygonum pulchrum B1. Int J Pharm Pharm Sci 2014;6:350-4.

12. Sahidin I, Suwandi A, Nohong N, Manggau MA. Profile of anticancer and radical scavenging activities of steroidsfrom stems of Polygonum pulchrum. Int J Pharm Sci Res 2015;6:2178-84.

13. Jalil J, Sabandar CW, Ahmat N, Jamal JA, Jantan I, Aladdin NA, et al. Inhibitory effect of triterpenoids from Dillenia serrata (Dilleniaceae) on prostaglandin E2 production and quantitative HPLC analysis of its koetjapic acid and betulinic acid contents. Molecules 2015;20:3206-20.

14. Hartati R, Suganda AG, Fidriyanni I, Ginting TM. Total flavonoid content and antimicrobial properties of four species of Zingiberaceae. Int J Pharm Pharm Sci 2014;6:142-4.

15. Poulsen AD. Etlingera of Sulawesi. Sabah: Natural History Publications; 2006.

16. Chan EW, Lim YY, Ling SK, Tan SP, Lim KK, Khoo MG. Caffeoylquinic acids from leaves of Etlingera species (Zingiberaceae). LWT Food Sci Technol 2009a;42:1026-30.

17. Williams CA, Harborne JB. The leaf flavonoids of Zingiberales. Biochem Syst Ecol 1997;5:221-9.

18. Mahdavi B. Chemical constituents of aerial parts of Etlingera brevilabrum (Zingiberaceae). Der Pharm Chem 2014;6:360-5.

19. Yahya MA, Yacob WA, Nazlina I. Isolation of chemical constituents from rhizomes of Etlingera sphaerocephala Var. Grandiflora. Malays J Anal Sci 2011;15:22-6.

20. Ficker CE, Smith ML, Susiarti S, Leaman DJ, Irawati C, Arnason JT. Inhibition of human pathogenic fungi by members of Zingiberaceae used by the Kenyah (Indonesian Borneo). J Ethnopharmacol 2003;85:289-93.

21. Chan EW, Lim YY, Wong SK, Lianto FS, Wong SK, Lim KK, et al. Antioxidant and tyrosinase inhibition properties of leaves and rhizomes of Zinger species. Food Chem 2008;109:477-83.

22. Lachumy SJ, Sasidharan S, Sumathy V, Zuraini Z. Pharmacological 
activity, phytochemical analysis, and toxicity of methanol extract of Etlingera elatior (torch ginger) flowers. Asian Pac J Trop Med 2010;3:769-74.

23. Wijekoon MM, Bhat R, Karim AA. Effect of extraction solvents on the phenolic compounds and antioxidant activities of bungakantan (Etlingera elatior Jack) infloroscence. J Food Comp Anal 2011;24:615-9.

24. Chan EW, Lim YY, Wong SK, Lim KK, Tan SP, Lianto FS, et al. Effects of drying methods on the antioxidant properties of leaves and tea of ginger species. Food Chem 2009b;113:166-72.

25. Chan EW, Lim YY, Omar M. Antioxidant and antibacterial activity of leaves of Etlingera species (Zingiberaceae) in Peninsular Malaysia. Food Chem 2007;104:1586-93

26. Chiang EC, Yan LY, Ali NA. Composition and antibacterial activity of essential oils from leaves of Etlingera species (Zingiberaceae). Int $\mathrm{J}$ Ambient Syst Appl 2010;1:1-12.

27. Sudhakaran A, Radha RK. Evaluation of accute and dermal toxicity of essential oil of Etlingera fenzlii (Kurz) K. Schaum: An in vivo study. Int J Pharm Pharm Sci Int J 2016;8:69-72.
28. Chacha M, Bojase-Moleta G, Majinda RR. Antimicrobial and radical scavenging flavonoids from the stem wood of Erythrina latissima. Phytochemistry 2005;66:99-104.

29. Fidrianni I, Utari P, Ruslan KW. Evaluation of antioxidant capacities, flavonoid, phenolic, carotenoid content from various extracts of four kinds brassica herbs. Int J Pharm Pharm Sci 2014;6:268-72.

30. Lin RJ, Yen CM, Chou TH, Chiang FY, Wang GH, Tseng YP, et al. Antioxidant, anti-adipocyte differentiation, antitumor activity and anthelmintic activities against Anisakis simplex and Hymenolepsis nana of yakuchinone a from Alpinia oxyphylla. BMC Complement Altern Med 2013;13:1-13.

31. Riaz T, Abbasi MA, Aziz-Ur-Rehman AU, Ajaib M. Isolation, structure elucidation and antioxidant screening of some natural products from Colebrookia oppositifolia. Biosci Res 2012;9:68-76.

32. Goss JA. Physiology of Plants and Their Cells. New York: Pergamon Press Inc.; 1973. p. 286.

33. Turkoglu A, Kivrak I, Mercan N, Duru ME, Gezer K, Turkoglu H. Antioxidant and antimicrobial activities of Morcella conica Pers. Afr J Biotechnol 2006;5:1146-50. 